\title{
THE IMPLEMENTATION OF PESANTREN EDUCATION SYSTEM IN STUDENT INDEPENDENT LEARNING AT AR ROMMEL DORMITORY PESANTREN DARUL ULUM JOMBANG
}

\author{
Ali Muhsin \\ University of Pesantren Tinggi Darul Ulum \\ alimuhsin@fai.unipdu.ac.id
}

\begin{abstract}
The purpose of this study is to describe the Implementation of the Islamic Boarding School Education System in the Self-Reliance of Santri in Learning at the Ar Rommel Boarding House at the Darul Islamic Boarding School 'Ulum Peterongan Jombang. This study aims to find out information about the pesantren education system in Ar Rommel's Dormitory. This research is a qualitative research,). Data collection techniques in this study was direct observation, interviews, and documentation. The results showed that: (1) The existence of Pesantren education system in Ar Rommel dormitory is reading a yellow book, recitation (fasholatan, istighosah, and surah in the Qur'an), reading the Qur'an. (2) the student independence is not merely assessed from their learning, but in the spirit of independence, including the category of independence such as increasing self-confidence (3) Implementation of supporting factors in the pesantren education system at the Ar Rommel dormitory, are responsibility and togetherness, teachers (asatidz ) comes on time. Furthermore, the implementation of the inhibiting factors of the pesantren education system in this dormitory is students who are late to join the teaching and learning process and teachers (asatidz) who cannot participate in teaching activities due to private events.
\end{abstract}

Keywords: Islamic Boarding School Education System, Santri Independence Learning

Islamic boarding school (pondok Pesantren) is Islamic educational institution which play role as a social institution. Their presence as the traditional Islamic educational institution contributes to well being of Indonesia education system.

Basically, pesantren is in Islamic term is a boarding house where the "santri" or student live together to study about religion under guidance the "kyai"(or senior religious teacher). The boarding house is in the pesantren nearby the kyai's house.

In Pesantren, there is non-formal education system which is called madrasah diniyah. System is components which is each part has different function. All parts of the system are integrated and work for reaching established goal. Education system is integrated part of all units which has correlation to each other to reach the purpose of education system ${ }^{1}$

In Indonesia, there are many educational institutions. They have different characteristic which represents their existence such as formal education (school), non-formal (society), and informal (family). In this case, Pesantren is one of developed educational institution which is recognized by the society around tem. They have a boarding house in which their students or santri get religioneducation through communal system or madrasah. Furthermore, in Pesantren, students have

\footnotetext{
${ }^{1}$ M.Arifin, Kapita Selekta Pendidikan Islam, (Jakarta: Bumi Aksara, 2003), 72.
} 
to learn independently. It aims to prepare them after studying at the pesantren. Independence is the aim of education process.

Among the developing educational institutions, Pesantren have strong characteristics in the context of the formation of independent students (santri). It shows by some evident especially in Pesantren Darul Ulum in Peterongan Jombang.

Based on the phenomena above, compared to formal educational institutions which differ from the start in terms of life and how to study, Pesantren Darul Ulum is capable build the students (santri) to live independently. Besides, pesantren Darul Ulum has many dormitory and also its teacher (kiai). Additionally, each dormitory also has its own education system. The system has its own way which characterize to encouraging students (santri) to fulfill and carry out the tasks of daily life independently ${ }^{2}$.

Based on the description above, the title of this study is " The Implementation of Pesantren Education System on Student Independent Learning At Ar Rommel Dormitory, Islamic Boarding House (Pondok Pesantren) Darul Ulum” to gain a necessary data.

\section{Research methods}

This study is a qualitative research. Denzin and Lincoln stated that qualitative research is research that uses a natural setting, with the intention of interpreting phenomena that occur and is carried out by existing methods ${ }^{3}$. Qualitative research requires in-depth analysis, because in this study it needs a deeper understanding of the scientific field as well as data and study sources ${ }^{4}$.

There are 2 types of data that researchers use namely primary and secondary data types. The primary data of interview and observation data, while secondary is supporting data in the form of documentation. Meanwhile, to collect additional data, then information is needed as a support of this study.

Furthermore, informant is individual that involved in this study. They provide information about the situation and conditions of the research background. The informant acts as an internal sampling because it is used to talk, exchange ideas or compare events found from many other subjects. The informant is assumed that the chosen person who has been considered can provide the right information as expected by the researcher.

To obtain data that is relevant to the problems specified above, the data is retrieved using the method:

Observation Method is the systematic observation and recording of the phenomena under investigation. Observation as a media to examine our objects or events directly. In this case, the researcher used the observation method to collect data by direct participating in the object under study to obtain the required data.

Interview Method is a method for obtaining information by question and answer directly between interviewers and informants. In this case Sutrisno Hadi said that the interview as a question and

\footnotetext{
${ }^{2}$ Uci Sanusi,'Pendidikan kemandirian dipondok pesantren’Jurnal Pendidikan Agama Islam-Ta'lim, Vol. 10 No. 2, (2012), 125

${ }^{3}$ Lexy J. Moleong, Metode Penelitian Kualitatif (Bandung: Remaja Rosda, 2016),
} 
answer process where two or more people face each other physically and listen to their own voice, seems to be a direct data collection tool (information) about several types of social data, both integrated and manifest. In this case, the researchers made a list of the question to be answered by the respondents dealing with The Implementation of Pesantren Education System on Student Independent Learning At Ar Rommel Dormitory Islamic Boarding House (Pondok Pesantren) Darul Ulum in order to obtain the required data.

The documentation method is a method used to collect data through documents related to research problems. This method is used to find data about things or variables in the form of notes, transcripts, books, newspapers, magazines, minutes, meetings, agents and so on. In this study, the method of documentation used to me ncari data about the state of students, teachers (cleric), the background of the hostel, the educational system as well as to a passage means and infrastructure in Ar Rommel Dormitory, Pondok Pesantren Darul Ulum Jombang .

In data analysis, researchers used technique of data triangulation. This technique is called checking data by utilizing various sources of data external data, that have been obtained as material for comparison or comparison of data. They are ${ }^{5}$ :

1. Comparing observation results with interview data, interview data with documentation data, documentation data with observation data. The results of this comparison will be unified data

2. Researchers examined obtained data by using different methods they are interviewing, observing and documenting and then put together to obtain valid data

3. Triangulation of data sources, i.e. Comparing real data obtained from both the time dimension and other sources, for example by comparing data obtained from interviews with principals or guidance councelling teacher.

\section{Discussion}

The system comes from Latin (sistema) and Greek (sustema) is a set of elements or elements that are interrelated and influence each other in carrying out joint activities to achieve a goal ${ }^{6}$. The system according to experts is: 1) Davis, GB, the system is a combination of elements that work together to reach the target, 2) harijono djodjodihardjo, the system is a combination of objects that have a functional relationship and the relationship between each object, as a whole a functioning unit. While Education is an effort or plan to create an atmosphere of learning in the learning process so that students actively develop their potential to have the strength of religious values, self-control, personality, intelligence, noble character, and the skills needed by themselves, society, nation, and country. So, the education system is the totality of interactions of a set of educational elements that work together in an integrated manner, and complement each other to achieve the achievement of an educational goal that has become a common goal.

Components are part of a system that has a role in the overall course of a process to achieve system goals. The education component means the parts of the education process system, which determine

\footnotetext{
${ }^{5}$ Wiratna. Sujarweni V. Metodologi Penelitian (Yogyakarta: Pustaka Baru Press. 2014), 32.

${ }^{6}$ A. K. Ahmad Muda, Kamus Lengkap Bahasa Indonesia. (Jakarta : Reality Publisher, 2006), 45.
} 
the success or failure of the education process. It can even be said that for the ongoing work process of education it is necessary to have these components ${ }^{7}$.

Islamic boarding schools, names and terms that may be familiar to Indonesian Muslim communities. He is an educational institution and religious institution that is typical of Muslim communities in Indonesia. So called, because in the place where Islam was born, the term boarding school was not found. Therefore, it is true to say that Islamic boarding schools are typical Indonesian Islamic educational institutions that were formerly known as Nusantara.

The pesantren had already been born even when compared to the birth of Indonesia itself, which was newly independent in 1945. Therefore, it is also natural to say that the role and participation of pesantren has been done quite a lot and has long been measured in the lives of Indonesian Muslim communities, especially in society. which inhabits the islands of Java and Madura.

The pesantren was brought by the saints who spread the teachings of Islam in the Archipelago around the XV and XVI centuries AD. These trustees, in Java, are implied by the name "Wali Songo". Although the influence of the arrival of "Wali Songo" reached the entire archipelago, but, his existence was only in Java. Because of this, it is almost also difficult to find graves of saints outside Java. Since those trustees, Islamic boarding schools have established themselves as institutions and social institutions as well as Islamic educational institutions.

Referred to as a social institution, because pesantren has played an ideal role as a social institution. He is accommodating as well as distributing the interests of the Muslim community at the local, regional, national and even international level.

In the opinion of scientists, the term pesantren is two terms that contain one meaning. Javanese people call it "pondok" or "pesantren". Often also referred to as boarding schools. The pesantren is actually the oldest educational institution in Indonesia, which in fact has given birth to many scholars. Not a few Islamic figures were born from Islamic boarding schools. He said that there had never been scholars who were born from institutions other than pesantren. The term 'pesantren' is derived from the word 'santri' '- an, where the word "santri" means students in Javanese. The term "pondok" comes from the Arabic "funduq" which means lodging. Specifically in Aceh, pesantren are also referred to as " dayah "8.

Whereas in terms of the understanding of pesantren staff in the opinion of experts, among others: M. Dawam Rahardjo gives the understanding of pesantren as an educational institution and broadcasting of Islamic religion that is the identity of pesantren at the beginning of its development ${ }^{9}$.

From the lengthy description above it can be concluded that the understanding of Islamic boarding school is an educational and religious institution that seeks to preserve, teach and spread Islam and train students to be ready and able to be independent.

\footnotetext{
${ }^{7}$ Amirin, Tatang M., Pokok-pokok Teori Sistem, (Jakarta: Rajawali Pers. 1992)

${ }^{8}$ Dokumentasi majelis pondok pesantren Darul Ulum “pondok pesantren” (jombang, 6 januari 2019)

${ }^{9}$ Zamakhsyari Dhofier, Tradisi Pesantren, (Jakarta : LP3ES, Edisi Revisi. 2015), 18.
} 
Pesantren as an educational institution has four basic elements of the pesantren tradition, namely Kiai, santri, teaching of classical Islamic books and mosques. Another opinion states that in Islamic educational institutions called pesantren there are always elements of the kiai who teach and educate, santri who learn from the kiai, mosques and huts where the santri live ${ }^{10}$.

The purpose of Islamic boarding school education is "Creating and developing Muslim personalities, namely personalities who believe in and devote to Allah SWT, have good character, be beneficial and serve the community by becoming a community servant or servant. Ideally the intended personality development is the personality of Muhsin, not just a Muslim. The purpose of pesantren education is not to pursue the interests of worldly power, money and grandeur, but learning is an obligation and dedication to God. Therefore the educational process is not merely to enrich the minds of the students with explanations, but to elevate morals, train to enhance spirit, respect spiritual and human values, teach honest and moral attitudes and behavior and prepare students to live simply and clean heart ${ }^{11}$.

Therefore, to find out the purpose of the education organized by the pesantren, the path that must be taken is to understand the functions carried out and developed by the pesantren itself both in relation to the students and the surrounding community ${ }^{12}$.

This was also done by the saints in Java in pioneering an Islamic educational institution, such as Sheikh Maulana Malik Ibrahim, who was considered the founding father of Islamic boarding school. Sunan Bonang or also Sunan Giri. That is they set up a boarding school aimed at the institution used to spread religion and a place to study Islam ${ }^{13}$.

KH. Abdurrahman Wahid or commonly called (Gus Dur) said that pesantren have an important role to teach religion, namely the basic values and elements of Islam. And pesantren as a social cultural institution, means that its function and role are aimed at the formation of an ideal society ${ }^{14}$.

\section{Types of Pesantren Education Systems}

Sorogan The word sorogan comes from Javanese Sodoran or which is meant to mean an individual learning system where a santri is dealing with a teacher, there is an interaction of getting to know each other ${ }^{15}$. A kiai or teacher faces one by one, in turn. While in its implementation, students came together, but the students queued to wait their turn.

This sorogan system illustrates that the kiai in providing his teachings is always goal oriented, always trying to make the students concerned read, understand and explore the contents of the book. With the existence of a teaching system with this sorogan a kiai is able to directly evaluate the ability of students, and the relationship between students and kiai more closely.

\footnotetext{
${ }^{10}$ Imam Bawani, Tradisional dalam Pendidikan Islam, (Surabaya: al-Ikhlas, 1993),

${ }^{11}$ Istihana,"keterampilan hubungan sosial santri di pesantren". Al-tadzkiyyah: jurnal pendidikan islam, vol. 6, november 2015, 285.

${ }^{12}$ Abdurahman Wahid. Bunga Rampai Pesantren, (Jakarta: Dharma Bakti, 1979),

${ }^{13}$ Marwan Sarisjo, Sejarah Pondok Pesantren Indonesia, (Jakarta: Dharma Bakti, 1980), 4.

${ }^{14}$ M. Dawam Rahardjo, Editor Pergaulan Dunia Pesantren, (Jakarta: LP3ES, 1985),

${ }^{15}$ Hasbullah, op.cit. 50.
} 
Through sorogan, Kyai's intellectual development can be captured in its entirety. He can give teaching pressure to certain students on the basis of direct observation of their basic abilities and capacities. Conversely, the application of the sorogan method requires patience and tenacity of teachers. Santri are demanded to have high discipline. In addition to the application of this method requires a long time, which means less effective and efficient ${ }^{16}$.

Wetonan Wetonan or bandongan method is the most important method in the pesantren environment. The wetonan (bandongan) method is a method of teaching by the teacher reading, translating, explaining and writing Islamic books in Arabic, while a group of students listens. They pay attention to their own books and take notes (both meaning and information) about difficult words or thoughts.

Wetonan in practice always focuses on pumping material without going through strict goal control. In this method, students are free to take lessons because they are not absent. The clerics themselves may not know the students who did not attend the lessons, especially their numbers of tens or even hundreds of people. There is an opportunity for sanri not to take lessons. While students who take lessons through wetonan are those who are in the middle level ${ }^{17}$.

The sorogan and wetonan methods both have very strong understanding characteristics in textual or literal understanding. However, that does not mean the sorogani and bandongan methods have no advantages at all. There are certain things that are felt as an advantage.

The term wetonan comes from Javanese which means periodic and time. Wetonan is a form of daily routine, but is carried out at certain times. For example, held every Friday, Fajr prayer and so on. The kiai reads the book in a certain time and the santri brings the same book listens and listens to the Kiai's reading. There are no attendance provisions, so students can come or not. In this case it can be said that the teaching system at the boarding school is free, free to learn and not learn ${ }^{18}$.

In this teaching system what Kiai read cannot be ascertained because sometimes the book is not determined and sometimes it is also determined. Whereas in the delivery to students of various kinds, some are given meaning and some are interpreted freely.

According to Banghart and Trull the system is a group of interrelated elements that are jointly directed to achieve the goals set. Then according to Murdick and Roos the system is a set of elements that carry out an activity in order to achieve the goal. So it can be concluded that the system is a whole set of parts with each other interacting and jointly carrying out activities to achieve goals ${ }^{19}$. Whereas according to Mukti Ali the Islamic education and teaching system in Indonesia is the best education system that follows the boarding school system, while the teaching follows the madrasa system, in other words the madrasa in the boarding school is the best form of Islamic teaching and education ${ }^{20}$.

\footnotetext{
${ }^{16}$ Dhofier., Tradisi Pesantren., 28.

${ }^{17}$ Qomar, Pesantren., 143.

${ }^{18}$ Mukti Ali, Beberapa Persoalan Agama Dewasa Ini, (Jakarta: Rajawali Press, 1987). 19.

${ }^{19}$ Syaiful Sagala, Administradi Pendidikan Kontemporer, (Bandung, Alfabeta), 9.

${ }^{20}$ Mukti Ali, op.cit, 20.
} 
The Pesantren Education System is a suggestion in the form of a device or mechanism created to achieve the goals of education and teaching that take place within the boarding school.

The education system in Islamic boarding schools still does not have basic similarities beyond the use of mandatory books (muubarrarah poles) which are almost the same or outside the adjacent subject matter. This diversity arises as a result of inequality in the education system, where there is a pesantren with an education system in the form of no schools or madrassas, there are pesantren that only use the madrasa education system classically, and there are pesantren that combine between the teaching system and the non-classical madrasa system. In this non-classical madrasa system, subject matter is given in succession from old books that are commonly used in the study. Santri Independence

Independence According to Indonesian dictionary, independence comes from the word Mandiri which means that the situation can stand alone or not depend on others. Then the meaning of independence is a thing or condition can stand alone without depending on others ${ }^{21}$.

According to Bathia quoted from Chabib argues that independent behavior is a behavior whose activities are directed at oneself, do not expect direction from others in solving the problems at hand $^{22}$. The external factors that influence children's independence are family influences on children, this factor is a factor that includes educational activities in the family, the tendency of how to educate, how to give an assessment to children, even to the way of life of parents influences the independence of children .

\section{Forms of Independence}

Emotional Independence is the ability to control one's own emotions and does not depend on the emotional needs of others.

Economic Independence is the ability to manage their own economy and does not depend on the economic needs of others.

Intellectual independence is the ability to overcome various problems encountered.

Social independence is the ability to interact with others and not depend on the actions of others ${ }^{23}$.

The Characteristics of Independence

Emotional independence is an aspect of independence that is associated with changes in approach or the relationship of individual emotional relationships, especially with parents or other adults who interact a lot with themselves.

Independent action is the ability to make decisions freely, follow through, and take responsibility. Independent thinking is the freedom to interpret a set of principles about right-wrong, good-bad, and what is useful for him.

Santri The term "santri" konong comes from the Sanskrit "Shastri", meaning people who learn sacred sentences and worship. The Wali Songo later adopted the term as "santri". Incorrect

\footnotetext{
${ }^{21}$ Depdikbud, Kamus Besar Bahasa Indonesia, (Jakarta: Balai Pustaka, 1989), 555.

${ }^{22}$ M. Chabib Thoha, kapita Selekta Pendidikan Islam, (Yogyakarta: Pustaka Pelajar,1996), 121.

${ }^{23}$ Desmita, Op.Cit. 186
} 
pronunciation in this case is common, for example, the word "shahadatayn" in Java becomes "sekaten" and as follows. So "shastri" or "santri" is a person who learns holy and beautiful sentences, which in Wali Songo's view means the holy book of the Qur'an and hadith. The sacred sentences are then taught, understood and manifested in daily life. In the big Indonesian dictionary, santri means people who study Islam ${ }^{24}$. Whereas the origin of the word "santri" in Nurcholish Madjid's view can be seen from two opinions. First, the opinion that says "santri" comes from the word sastri, a word from the Sanskrit language which means literacy.

The yellow book which is the Islamic treasure of the ulama al-salaf al-shalih product, is used as a guide by the kiai, nyai and santri to understand the substance of the teachings contained in the Qur'an and hadith. Pesantren is the legacy of the Wali Songo. He mingled in the midst of the Nusantara community and preached with the method of acculturation, appreciating local traditions and wisdom, and providing adherence to hold on the Qur'an, the hadith and the yellow book. The Songo Guardians were the ones who brought the yellow book to the archipelago which until now was taught at the pesantren. He taught a long time ago holy and beautiful sentences, by which they built al-akhlaq al-karimah.

Santri Kinds

Santri Mukim are students who come from distant areas and settled in a boarding school group. The santri who live in the pesantren for the longest time are usually a separate group that has the responsibility to take care of the daily interests of the pesantren. The brand also bears the responsibility of teaching young students about basic and secondary books.

Santri kalong are students who come from villages around the pesantren, which usually do not settle in pesantren. To follow their lessons at pesantren, they go back and forth from their own homes, usually the difference between large pesantren and small pesantren can be seen from the composition of the santri kalong ${ }^{25}$.

Santri's independence is an attitude that shows not only related to things that are moral and spiritual, but also material. That is, pesantren not only develop an attitude of independence of students in matters that are ritual or worship, but also material.

Independence is an attitude that is very needed by someone in carrying out their life activities, on the contrary dependence on people or other parties is a bad trait, because he will give birth to lazy and weak spirit and are reluctant to try, which will ultimately harm yourself and others. Selfreliance is an attitude or ability and willingness of a person to live without depending on his fate to others, because humans are essentially "themselves", will return to their own origin, and take responsibility for all their own deeds themselves, without anyone being able to help and go with ${ }^{26}$.

\section{A Brief History of Ar Rommel's Dormitory}

\footnotetext{
${ }^{24}$ Depdikbud, Kamus Besar Bahasa Indonesia (Jakarta: Balai Pustaka,1989), 783.

${ }^{25}$ Zamakhsyari Dhofier, Tradisi Pesantren,(Jakarta: LP3ES, Edisi Revisi. 2015), 51.

${ }^{26}$ Juwariyah, Pendidikan Moral dalam Puisi Imam Syafi'i dan Ahmad Syauqi, (Yogyakarta: Bidang Akademik, 2008), 174
} 
At the beginning of the establishment of the Dormitory which is now named Ar Rommel Dormitory formerly called Al Burdah, was founded directly by KH. Romly Tamim \& Nyai Hj. Khodijah which is his residence (ndalem), in the old times the Al Burdah dormitory was not terraced as it is now and its dormitory was still on the ground floor or ground and there were still many pages which were now used as the living room of the Ar Rommel Hostel. And in 1985 the Al Burdah Boarding House renovated, so all the temporary dormitory equipment was moved to the Al Ghozali dormitory but the students continued to follow the activities and directions of the caregivers, so began eating, boarding activities were carried out in the old pavilion. After the following year in 1986 the Al Burdah dormitory remained below, however the one on the floor was named the Al Kautsar dormitory at that time who carried out the construction he was directly KH. Rifa'i Romly is now used as a place for santri bathrooms. And in 1985 the first son of KH. Romly Tamim named KH. Musta'in Romly died, and in 1995 the second son named KH. Rifa'i Romly also died at that time the Al Burdah hostel was still located on the lower floor and the upper floor was still the Al Kautsar hostel. At the time of $1996 \mathrm{KH}$. Tamim Romly asked for permission located on the second floor to be made by Al Burdah Dormitory until 2008-2009. Then in 1996 the story of the Al Burdah santri rarely went to the mosque to perform the congregational prayers, finally $\mathrm{KH}$. Tamim Romly was angry with her students, so the children who were housed under had all come out. The name Al Datra's dormitory itself was specially made to serve KH. Tamim Romly or another term Abdi ndalem was in 1997, and when in 2008-2009 it was renamed Ar Rommel A and B dormitory, which was located between the lower and upper floors. Romly Tamim as the right name for the founder, so in the past Al Burdah's child was comfortable because he was close to Mrs. Nyai Romly's caretaker, the same as Al Hambra's dormitory, so it was delicious KH. Musta'in Romly has a goat so he can goat her goats, and there is also the name of a 1001 boarding boy who is also raised by KH. Romly Tamim and Mrs. Nyai Khodijah, children of 1001 were also khadamnya KH. Musta'in Romly, in the past 1001 had been placed behind MIN (Madrasah Aliyah Negri) and Al Hambra dormitory had been placed in the DU 1 High School office on the second floor and was still in the era of KH. Musta'in Romly. So when Mrs. Nyai Romly was going down, some of her students also followed her as a solemn prayer to her and also her students were also sent by the Kasawah so it was comfortable there, for example, if there was a development process (casting) and a drainage system that automatically did the $\mathrm{Al}$ Burdah children, at the beginning of its establishment which is certainly still in the days of $\mathrm{KH}$. Romly Tamim, however, if giving the name of the hostel the first time the name Al Burdah was more or less around the 1970s, and his room at that time was still below what was now used as a warehouse and it was around the 1960s and at that time there was no the name of the hostel. So in the past there was only the main dormitory (son), then there was a 1 (one) dormitory building, KH. Mashhari Sahid, he was made the daughter-in-law of the KH family. Kholil, then increased to Dormitory 2 (two) which is now called Al KHodijah Dormitory (princess) and it was the first time boarding school for Darul 'Ulum Islamic Boarding School and its founder, KH. Romly Tamim and Mrs. Nyai Khodijah, only after the son of KH. Romly Tamin, who is married, has started other dormitories, such as boarding house 4 which is near the river and one of them is Gus Mujib and Mrs. Nyai A'an, when the house was 
established in 1984, KH. Musta'in Romly built what he wanted was housing for teachers up to the boarding school that had been planned by him, then in 1984 it began to be built but in January KH. Musta'in Romly died and the place was finally distributed to his brothers like KH. Shonhaji Romly, KH. Rifa'I Romly, KH. Hasyim, KH. Hanan, KH. Dimyati Romly. After that there was a hostel called Chosi'ah which was formerly the Undar tarbiyah building where the tarbiyah faculty was placed in a boarding house, and there were still many empty fields or fields, and who inaugurated Mr. Minister Bustanul Arifin he walked through the fields, when he wanted to go home through paddy field earlier these people immediately turned towards the ndalemnya Gus Mujib even though at that time it had been escorted by KH. As'ad Umar, whose intention was to be brought to the main boarding house and then the father of the minister came out of that escort and Gus Mujib went into his house just to look for the bathroom, because he wanted to urinate. Previously, Gus Mujib had been diamanahi or be supported by KH. Romly Musta'in more or less like this "Gus, lek gawe omah jedinge sing neatly, pawone sing penak" (Gus, if you make a nice bathroom house, nice yard). And the existing dormitories followed one after another in 1995 and above, such as Pondok Tinggi, Muzam dormitory, if they were like the dormitory of KH. Dimyati Romly and Asrama Asyafi'iyah existed before 1995, more or less around the 1980s. So after the development of the era that used to be called the Al Burdah hostel, then changed to Al Ar Rommel A and B, and starting in 2012 to become one, the Ar Rommel hostel did not distinguish between Ar Rommel A and B where the caregiver was named KH. A. Tamim Romly, for the blessing of Allah's grace, Alhamdulillah, who always guides his students until now ${ }^{27}$.

Profile of Ar Rommel Boarding House Pesantren Darul 'Ulum Peterongan Jombang ${ }^{28}$

Boarding Name : Ar Rommel Dormitory

Address KH. A. Tamim Romly (Jl. KH. Romly Tamim Rejoso Peterongan

Jombang)

Village : Rejoso

District : Peterongan

Regency / City : Jombang

Province : East Java

Telephone / Mobile : (0321) 864927, 872422

Vision

Building a true Muslim cadres actively carries out the teachings of their beliefs. Using the knowledge and science as a religious and state enforcer such as the slogan of the Pesantren Darul 'Ulum

Mission

Building a human who is familiar and always loves Allah. Through the belief that only the instructions will be able to create goodness.

\footnotetext{
27 Interview result with senior teacher at ar Romel, 8 Mei 2019

${ }^{28}$ Ar Rommel Boarding house Pesantren Darul Ulum
} 
Table 1

Daily Santri Activities Ar Rommel Boarding House ${ }^{29}$

\begin{tabular}{|c|c|c|c|}
\hline $\mathrm{NO}$ & TIME & TYPE OF ACTIVITY & INFORMATION \\
\hline 1 & $03.15-04.30$ & $\begin{array}{l}\text { Preparing for the Morning } \\
\text { Prayer }\end{array}$ & All Santri \\
\hline 2 & $04.30-05.00$ & Fajr Prayers and Istghosah & All Santri \\
\hline 3 & $05.00-06.00$ & Koran Al-Qur'an & All Santri \\
\hline 4 & $06.00-06.45$ & $\begin{array}{l}\text { Breakfast / School } \\
\text { Preparation }\end{array}$ & \\
\hline 5 & $\begin{array}{l}6: 45 \text { to } \\
13: 00\end{array}$ & School activity & Respective Unit \\
\hline 6 & $\begin{array}{l}1: 00 \text { to } \\
13: 30\end{array}$ & Dzuhur Prayer & All Santri \\
\hline 7 & $13.30-14.00$ & Lunch & \\
\hline 8 & $\begin{array}{l}\text { 2:00 to } \\
\text { 4:00 p.m. }\end{array}$ & $\begin{array}{l}\text { School Supplementary } \\
\text { Lessons }\end{array}$ & Respective Unit \\
\hline 9 & $\begin{array}{l}16: 16- \\
16.15\end{array}$ & Congregation of Asr Prayer & All Santri \\
\hline 10 & $16.15-17.00$ & Rest / Sports / Eating & \\
\hline 11 & $\begin{array}{l}17: 00- \\
17.30 \\
\end{array}$ & $\begin{array}{l}\text { Preparation for Maghrib } \\
\text { Prayer }\end{array}$ & \\
\hline 12 & $17.30-18.15$ & Maghrib Prayer & All Santri \\
\hline 13 & $18.15-19.30$ & Study of the Book & All Santri \\
\hline 14 & $19.30-20.00$ & Jama'a Prayers Isha ' & All Santri \\
\hline 15 & $\begin{array}{l}\text { 8:00 to } \\
\text { 9:00 p.m. }\end{array}$ & $\begin{array}{l}\text { Recitation of Diniyah } \\
\text { Tafaqquh Fiddin }\end{array}$ & All Santri \\
\hline 16 & $\begin{array}{l}\text { 9: 00-22: } \\
00\end{array}$ & Studying & All Santri \\
\hline 17 & $22.15-03.15$ & Curfew / Rest & All Santri \\
\hline
\end{tabular}

Source: Documentation at Ar Rommel Boarding house 2019

${ }^{29}$ Ar Rommel Boarding House Pesantren Darul 'Ulum Jombang 
Table 2

\begin{tabular}{|l|l|l|} 
Facilities and Infrastructure at Ar Rommel's Dormitory \\
\hline & & 30 \\
\hline NO & NAME OF GOODS & TOTAL NUMBER \\
\hline 1 & Santri Room & 6 \\
\hline 2 & The Yellow Book & 120 \\
\hline 3 & Safe & 120 \\
\hline 4 & Bathroom & 8 \\
\hline 5 & Fan & 6 \\
\hline 6 & Place of the Koran / Study & 1 \\
\hline 7 & Clothesline & 2 \\
\hline 8 & Loundry Clothing & 1 \\
\hline
\end{tabular}

The pesantren activity system at the Ar Rommel Hostel

The pesantren education system in the Ar Rommel Dormitory. Based on observations, interviews and documentation of researchers with boarding supervisors, there is an education system which focuses on learning Islamic religious values. Because without the pesantren education system a pesantren or boarding house will not experience any development where there is no activity at all in the pesantren, therefore in the boarding school Ar Rommel has formed a pesantren education system which is indeed represented for all students to attend. This is evidenced by the activities that include, guidance on reading the yellow book, memorization (fasholatan, istighsosah, letters in the Qur'an) and reading the Qur'an, it is one of the pesantren education system at the Ar Rommel Dormitory which is described as follows:

\section{Studying to read the yellow book}

The yellow book reading guidance activity is one of the pesantren education systems at Ar Rommel Dormitory, the activity is nothing but to guide the students to be able to read or study the yellow book, the goal is that the students not only know general knowledge, but also know the religious knowledge that was studied and composed by previous scholars. Regarding this matter, Ust az . Mukhlis S. Ip, as the coach of Ar Rommel's boarding house explained that: the activity of the guidance of reading the yellow book which was held at the Ar Rommel Boarding House was an obligation for every santri who settled in the Ar Rommel Dormitory, because from the first the student's name had to learn or know reading the yellow book, because for students it is an obligation that really must be read or understood what the yellow book is, so that students do not only know the general knowledge taught in formal schools, but reading the yellow book intends as

\footnotetext{
${ }^{30}$ Ar Rommel Boarding House Pesantren Darul ‘Ulum Jombang
} 
the basis for supporting religious learning and in the Ar Rommel Boarding House by using Sorogan $\operatorname{method}^{31}$.

\section{Memorized Koran}

This program include fasholatan, istighotsah, and surah in Koran. It is the program held in ar Rommel dormitory. This program is carry out to use the santri to memorize and understanding Koran. Beside, it also as an endowment at home when they have graduated.

This is emphasized in the students in order to form the personality of the students who diligently read the Koran. This statement was expressed by Mr. Ustaz Mukhlis S. Ip as a senior teacher. According to him, it is a must for every santri to memorize Koran in pesantren. This is a fardhu kifayah or obligation. Because if no one has memorized it at all, it will be afraid that there will be changes to the text that will be memorized. This is important students to do as a endowment at home when they have graduated

\section{Reciting Al-Qur'an}

In the process of reading the Qur'an at the Ar Rommel dormitory aims to practice how to read the Arabic alphabet and its pronunciation. The method is done by the listening method. The instructors are the teachers of the Qur'an. This is emphasized in the students in order to form the personality of the students who diligently read the Koran. This statement was expressed by Mr. Ustaz Mukhlis S. Ip as a senior teacher. According to him, it is a must for every santri to memorize Koran in pesantren. This is a fardhu kifayah or obligation. Because if no one has memorized it at all, it will be afraid that there will be changes to the text that will be memorized. This is important students to do as a endowment at home when they have graduated ${ }^{32}$.

\section{Conclusion}

Based on the results of the study, the following conclusions can be drawn:

1) The existence of Pesantren education system in Ar Rommel dormitory is reading a yellow book, recitation (fasholatan, istighosah, and surah in the Qur'an), reading the Qur'an. (2) the student independence is not merely assessed from their learning, but in the spirit of independence, including the category of independence such as increasing self-confidence (3) Implementation of supporting factors in the pesantren education system at the Ar Rommel dormitory, are responsibility and togetherness, teachers (asatidz ) comes on time. Furthermore, the implementation of the inhibiting factors of the pesantren education system in this dormitory is students who are late to join the teaching and learning process and teachers (asatidz) who cannot participate in teaching activities due to private events

The independence of students at Ar Rommel's Dormitory in studying religion is that they are sometimes accustomed to reading the yellow book before entering the teaching and learning process while memorizing. Besides that, some of the students of the Ar Romel boarding house are diligent to reading the Qur'an. Furthermore, the existence of students' independence is not merely in terms of learning. It is furthermore can be seen in their enthusiasm and desire to be improved, for

\footnotetext{
${ }^{31}$ Interview with senior teacher, 10 Mei 2019

${ }^{32}$ Interview with senior teacher, 10 Mei 2019
} 
example they can control themselves, are responsible, trustworthy, and confident, have concern for others, and are optimistic.

The implementation of supporting factors in the pesantren education system at Ar Rommel Dormitory has an impact on the behavior of worship habits, such as reading the yellow book at the time before the teaching and learning process. In addition, it also has an impact on academic tasks such as the enthusiasm of studying religion and working on boarding assignments both for students, teachers or students.

Furthermore, the impact of the pesantren education system at Ar Rommel dormitory affects the behavior of good habits of discipline in carrying out tasks such as1) The existence of Pesantren education system in Ar Rommel dormitory is reading a yellow book, recitation (fasholatan, istighosah, and surah in the Qur'an), reading the Qur'an. (2) the student independence is not merely assessed from their learning, but in the spirit of independence, including the category of independence such as increasing self-confidence (3) Implementation of supporting factors in the pesantren education system at the Ar Rommel dormitory, are responsibility and togetherness, teachers (asatidz ) comes on time. Furthermore, the implementation of the inhibiting factors of the pesantren education system in this dormitory is students who are late to join the teaching and learning process and teachers (asatidz) who cannot participate in teaching activities due to private events. Moreover, another inhibiting factors are facilities and blackout which disrupt the activity of the program.

\section{REFERENCES}

Amirin, Tatang M. 1992. Pokok-pokok Teori Sistem, Jakarta: Rajawali Pers.

Arifin, M. 2003. Kapita Selekta Pendidikan Islam, Jakarta: Bumi Aksara.

Bawani, Imam. 1993. Tradisional dalam Pendidikan Islam, Surabaya: al-Ikhlas.

Depdikbud. 1989. Kamus Besar Bahasa Indonesia, Jakarta: Balai Pustaka.

Dokumentasi majelis pondok pesantren Darul Ulum. 2019. “Tafaqquh fiddin” Jombang, 6 januari.

Dhofier, Zamakhsyari. 2015. Tradisi Pesantren. Jakarta : LP3ES, Edisi Revisi.

Hasil wawancara dengan Pembina Asrama Ar Rommel, 2019. "Pondok Pesantren Darul Ulum" 8 Mei.

Istihana, "keterampilan hubungan sosial santri di pesantren". Al-tadzkiyyah: jurnal pendidikan islam, November 2015, hal 285-305.

J Lexy. Moleong, 2016. Metode Penelitian Kualitatif Bandung: Remaja Rosda.

Juwariyah, 2008. Pendidikan Moral dalam Puisi Imam Syafïi dan Ahmad Syauqi, Yogyakarta: Bidang Akademik. 
Muda, Ahmad. 2006. Kamus Lengkap Bahasa Indonesia. Jakarta : Reality Publisher.

Mukti, Ali. 1987, Beberapa Persoalan Agama Dewasa Ini, Jakarta: Rajawali Press.

Rahardjo, Dawam. M. 1985. Editor Pergaulan Dunia Pesantren. Jakarta: LP3ES.

Sagala, Syaiful. Administradi Pendidikan Kontemporer, Bandung, Alfabeta.

Sanusi, Uci. 2012 ,Pendidikan kemandirian dipondok pesantren”Jurnal Pendidikan Agama Islam-Ta'lim, Vol. 10 No. 2, 125-139.

Sarisjo, Marwan. 1980. Sejarah Pondok Pesantren Indonesia. Jakarta: Dharma Bakti. Sujarweni, Wiratna.V. 2014. Metodologi Penelitian Yogyakarta: Pustaka Baru Press.

Thoha, Chabib. M. 1996. kapita Selekta Pendidikan Islam, Yogyakarta: Pustaka Pelajar.

Wahid, Abdurahman. 1979. Bunga Rampai Pesantren, Jakarta: Dharma Bakti. 
